\title{
DOUBLE CONSCIOUS BROTHER IN THE VEIL Toward an Intellectual Biography of Sterling A. Brown
}

by John Edgar Tidwell

Our home was graced with six children, five girls and one boy. ... The youngest of the family is a boy now 22 years of age. He finished the Washington High School, [sic] graduated with honor from Williams College, Williamstown, Mass., took the Master's Degree from Harvard and is now spending his first year as head of the English Department in the Virginia Theological Seminary and College, Lynchburg, Virginia. I am glad that he had the courage to select a position where not only the opportunity for teaching college subjects in keeping with his training, but, where the opening for larger service seemed to him superior to that proffered in the High Schools of Washington.

-Rev. Dr. Sterling Nelson Brown, My Own Life Story (37)

"I kin be a good bishop,

I got de looks,

An' I ain't spoiled myself

By readin' books.

"Don't know so much

'Bout de Holy Ghost,

But I likes de long green

Better'n most.

"I kin talk out dis worl"

As you folks all know,

An' I'm good wid de women,

Dey'll tell you so ...

\section{V}

"An' I says to all de Bishops,

What is hearin' my song-

Ef de cap fits you, brother,

Put it on."

—Sterling Allen Brown, "Slim Hears 'The Call"” 
"Of course you have fought
in language for what was real
about us, your mama's jim crow
fight on Howard's campus,
dozens in the half dozen
children she bore,
your father's facts
reborn in you, and you
fighting to be born in self,
transcending your poems
on traintracks bottomless
in Foggy Bottom,
pain and laughter of your people
in your people's word."
$\quad$-Michael S. Harper, "Williams College: after 51 years"

The writings of Sterling A. Brown (1901-1989), I will argue, are consumed with issues that grew out of Brown's paradoxical existence as a Negro (to use his preferred self-designation), as an intellectual, and as an American. As such, the constant struggle to forge a coherent personal identity out of these apparent contraries lends itself to exploration by way of an "intellectual biography," the chronicling of the nexus of life writing and its history of ideas. While there is no agreement about the nature or theory of intellectual biography, clearly such writing focuses on discernible tensions, oppositions, and reflexive discourse. Because Brown's familiar self-proclamation was to seek wholeness in his life, a significant opposition that engaged his mind and emerged in his art was the sacred world represented by his father which conflicted with his own embrace of the secular world. The preceding epigraphs are intended to suggest three different perspectives on Brown, which I will connect using Dr. DuBois's familiar metaphor of "double consciousness."

In the first epigraph, Rev. Dr. Sterling Nelson Brown (1858-1929) proudly speaks of his only son's recent employment by Virginia Theological Seminary and College, in Lynchburg, Virginia. The key sentence in Rev. Brown's "life notes and musings" is "I am glad that [my son] had the courage to select a position where not only the opportunity for teaching college subjects in keeping with his training, but, where the opening for larger service seemed to him superior to that proffered in the High Schools of Washington." On one hand, "larger service" expresses and represents an ideal employment opportunity privileging higher education at the college in Lynchburg over high school teaching in Washington. Certainly, Rev. Brown was aware of what we also know about employment opportunities for African Americans in Washington in the mid-1920s. As Jervis Anderson reminds us: "Those who were not lucky enough to be lawyers or doctors-and who did not wish to be postal clerks, low level government workers, soldiers, Pullman porters, or manual laborers-found that teaching was the best career open to them." ${ }^{11}$ For aspiring teachers, first Howard University and then Dunbar High School were the choicest pedagogical plums. 
Dunbar's reputation, in fact, was the equivalent of most Eastern seaboard prep schools; its prestige rested on a faculty who had either a BA, MA, or PhD and many who were Phi Beta Kappas. Another attraction for the instructional staff was that African-American teachers were paid the same salaries as their white counterparts. ${ }^{2}$

But "larger service" also reads like a wish, a hope, a desire that Sterling Allen, the only son and the youngest of six children, would take up the father's mantle and "hear the call" of the Seminary at this Virginia school. Sterling Allen implicitly testifies to his father's wishes in his familiar quip that Rev. Brown and historian Carter G. Woodson "sent" him South to learn something about his people. Read as something more than the son's penchant for telling "lies" (in other words, "tall tales"), Sterling Allen's view of "larger service" comes to signify, more profoundly, a son's polite disavowal of his father's wishes-an attitude that reveals itself in his art.

For example, the excerpt from "Slim Hears "The Call'" tells us that the tall taletelling Slim denounces religious leaders in terms that critic Jean Wagner describes as "so bitter that it borders on cynicism.." We can assume the younger Brown indeed loved and admired his father. (See, for example, the poem "After Winter," the homage to his father that echoes with the refrain: "An' fo' de little feller/Runnin' space....") But familial love was not strong enough to lure Sterling Allen into the ministry. On the contrary, what can be argued is that while both father and son shared a deep and abiding love for the "folk," their love held very different significations. As a result, what may appear to be a simple case of adolescent rebellion, anxiety of influence, or "son slaying the father" poses, instead, a complex cultural issue about how best to fulfill a father's wishes while, at the same time, maintaining one's own integrity. As the lines from the third epigraph say: "your father's facts / reborn in you, and you / fighting to be born in self ..." This internal conflict produces what I'd like to discuss as Sterling Allen's double consciousness.

The term "double consciousness" has been conveniently subjected to various interpretations. Generally, though, the term has been used either to promulgate DuBois's theory about reconciling "two warring identities" or to explain tropologically the ideas of writers advancing their own theoretical positions. ${ }^{4}$ For my purposes here, though, I plan to adapt "double consciousness" as Michael Awkward defines it. He writes: "Certainly, one way to conceive of the Afro-American's attempt to resolve double consciousness is as a struggle to be initiated into the larger American society. Such a struggle does not necessarily conclude in acceptance by that society ..., to be sure. In other words, Afro-American double consciousness is not always resolved." Prof. Awkward's definition of the term is poignant because it describes Sterling Allen Brown's now familiar self-described pursuit to be acknowledged as a full-fledged American citizen. In his retrospective speech given at Williams College, Brown reminded us: "I am an integrationist ... And by integration, I do not mean assimilation. I believe what the word means-an integer is a whole number. I want to be in the best American traditions." 6 This quest for wholeness, this unceasing effort to fill in the fractional status accorded African Americans by the framers of the Constitution when slaves, for purposes of taxation, were counted as three-fifths of a person, undoubtedly forms part of Brown's double consciousness. Ultimately, the question whether Brown 
actually resolved it is raised. In this essay, I'd like to focus my attention more narrowly on the difficulties of answering this question by examining the issue of "larger service" announced by Rev. Brown in his life story.

Rev. Brown's idea of "larger service" emerged from a life which slowly, painfully, and often, at great personal sacrifice evolved out of a beginning in slavery; through the attainment of four academic and honorary degrees, to pastorates at Congregationalist churches in Nashville, Cleveland, and Washington, D.C., that were largely failing until he assumed control; culminating in a professorship at Howard University's Theological Department. The ideology informing Rev. Brown's "larger service," in part, responds to the critique of the Southern Negro clergy made by his friend and confidante Booker T. Washington, as largely uninformed, uneducated, and illprepared to provide "mental and moral" leadership to African Americans. ${ }^{7}$ Although Washington's motives for lambasting the clergy, as critics such as Robert Stepto intimate, ${ }^{8}$ were somewhat self-serving, his critique of pastoral leadership was not without some merit. Barely thirty-five years out of slavery, few ministers had the theological training and educational leadership necessary to shepherd successfully their flocks of largely untutored sheep. "Larger service," in this way, points to the prevailing middle-class preoccupation with "racial uplift." While Washington pursued a solution through material gain, Rev. Brown sought to uplift the race by empowering a growing body of clergy educationally and by addressing the practical needs of church members and those who were euphemistically called "the unchurched."

To strengthen the clergy, Rev. Brown responded to a request from the wife of a poorly educated Southern pastor for educational advice. As a result of this initial inquiry, made around 1910, he created the Correspondence Study and Extension programs for the School of Religion at Howard. ${ }^{9}$ At the same time, he addressed the needs of church members and "the unchurched" by participating in what was called the "institutional church" movement. As he said:

The churches must be more practical and less sentimental.... let there be training classes, mothers' and children's meetings. ... Let our pulpits and press rebuke crime among us as well as away from us. Let us organize and encourage good citizenship committees in all our churches and in every community. Let us draw the line between the idle and industrious among us. Let us urge vagrant laws upon that set of men who will not work but form the criminal class in all our cities. ${ }^{10}$

As practiced at Lincoln Memorial Temple Congregational Church, "institutional features" included: "Christian Workers' Training School, a first-class Business College, Day and Night Preparatory School, Working Women's Clubs, Household Training Department, Boys' and Girls' Clubs, Employment Exchange, Penny Savings Bank, Social Settlement Center and Reading Room."11 In careers as pastor and theologian, spanning some forty-odd years, Rev. Brown was indefatigable in making the Puritan-inspired Congregationalist spiritual and work ethics function in the service of uplifting African-American people. 
There is little doubt that the fervor expressed in Rev. Brown's evangelical and other theological efforts formed the basis for the family values in the Brown household. "My father," wrote Sterling Allen, "was a stern man-very high ideals."12 For example, Rev. Brown did not suffer sinners gladly; as he wrote:

Impatient as I have always been with the drinking man in church and with the inexcusable method of securing money to run the Lord's work, by chance, grab bags, and dance halls, my protest has been inevitably met with a cruel obstinacy and resentment. ... For daring to preach against two evil places near my church, one a dance hall and the other far worse, I was threatened and intimidated but without avail. . . .13

Had the younger Brown followed in his father's footsteps, we certainly would have seen the same energy and commitment exerted in the son's efforts to emulate his father's ways. But, as we well know, Sterling Allen took a different fork in the road. By virtue of the road not taken, we have a very different view of the folk preserved for us. "I learned the Arts and Sciences at Williams [College]," Sterling said about his education, "[and] I learned the Humanities in Lynchburg, Virginia." 14 The results of his "humanistic" study have been carefully compiled by Robert O'Meally in a wonderfully comprehensive bibliography of Brown's published writings. But because neither of the Browns left an extensive autobiography or memoir, we have no detailed discussion of the father-son relationship. Anecdotally, however, we can infer some differences: against the father's austerity about smoking and drinking, Sterling Allen, of course enjoyed a fine glass of whiskey and a pipe of good tobacco. However, in deference to his father's memory, Sterling would never enjoy such delights in his mother's house. More important though, Sterling turned to the folk not to save their souls or uplift them; instead, he found them to be sources of cultural authenticity, purveyors of philosophical wisdom, and communicators par excellence of vernacular speech. For Sterling Allen, then, the idea of "higher service" represents an aesthetic duty. Particularly as a poet, he reclaimed the humanity of African Americans through astutely drawn literary portraits and by refashioning expressive forms in innovative ways. Like the Irish playwright John Synge ${ }^{15}$, Sterling went out among the folk to absorb their lives, language, and lore. He spent summers teaching school at Manassas (in Virginia) and at Atlanta University so that he would be free to scour the countryside for Black folk who had yet to succumb to such cultural intrusions as the radio and black-top roads. His quest, not unlike Jean Toomer's and Zora Neale Hurston's, was to preserve a rich cultural heritage before this legacy was changed forever.

Unlike Rev. Brown's participation in the cause of racial uplift, Sterling Allen found Black folk life, language, and lore, as I said before, to form the basis of racial authenticity. The son clearly departs from his father's sincere efforts to improve the image of the race, a gesture that can be read as a response to the father's attempt to raise the folk to middle-class respectability. The son's aesthetic expressivity, in contrast, probed the depths of folk life to reveal their humanity, which was often obscured by stereotyping or superficial representations. By seeking, as Edwin Arling- 


\section{A L L A L O O}

ton Robinson said, the "extraordinary in ordinary life," Brown the poet came to understand Black folk in ways that differed from his father.

Brown's poems that thematically focus wholly or partially on Black folk religion represent not simply different views on the subject, but, as I would argue, a dual consciousness about organized religion itself. Beyond the biographical information describing such predilections as alcohol consumption, or what William Raspberry reports as an eclecticism "which equalizes 'Georgia Moon' and 'Haig and Haig Pinch,"'16 the personal practices of the son that differ from his father's preachments reveal themselves tropologically in a short list of poems. Among a group that includes "When de Saints Go Ma' ching Home" (26), "Maumee Ruth" (24), "Seeking Religion" (33), "Sister Lou" (54), "Checkers" (71), "Elder Mistletoe" (148), and "Temple" (168), the most scathing view of organized religion is found in "Slim Hears "The Call" (83). ${ }^{17}$

A narrative poem, "Slim Hears 'The Call'" draws many of its techniques from the American tradition of tall tale or "lies," made famous by 19th-century satirists, including Mark Twain. Among folklorists, collectors of tales, and even literary critics, some agreement exists that the "lie" is an exacting art form, which means that it has its own structural integrity and coherence. While some writers determine the quality of the achievement by the size of the tale's exaggeration, others, including Sterling A. Brown, lament that the size of the exaggeration often supplants the more important "fixin's," much to the detriment of the tradition. ${ }^{18}$ The truer artistic expression, in other words, is found in the many stylistic devices employed by the speaker, including understatement, the occasional truthful element, its logic and structure (that is, its development from plausibility to climax), and the crucial pause at the point of highest suspense (which is intended to induce a listener to ask a question, therefore, revealing his gullibility). ${ }^{19}$

Despite its artistry, "Slim Hears 'The Call,'" the least funny poem in the Slim Greer series, has been described as surrendering to bald social statement. Critics have largely seen "Slim Hears "The Call" as sardonic because its nearly Swiftian descent from wry amusement at the folly of racism in the other Slim Greer poems becomes, in their view, a more vocal expression of outrage at religious hypocrisy. Jean Wagner, as I mentioned earlier, was moved to observe in this poem a "greater bitterness and more chilling cynicism" that could only have been generated by the Marxist ideology that had an appeal for Black intellectuals after the Crash of $1929 .{ }^{20}$ Understandably, the rather blatant warning that concludes the poem has incited many of these views: "An' I says to all de Bishops, / What is hearin' my song- / Ef de cap fits you, brother, / Put it on" (88). Although the harsher tone of this poem differs from that of the others, the use of tall tale techniques rescues it from the pessimistic mire to which Wagner condemns it and, from those bold enough to say it, a personal attack on Rev. Brown.

The ultimate effect of "Slim Hears "The Call'" derives largely from its performance milieu and rhetorical embellishment. "Down at the barbershop / Slim had the floor" announces place and performative environment. As in the other poems, much of the subsequent exaggeration must be seen in the context of verbal jousting with an hypostatized audience. The nearly down and out Slim is "So ragged, I make a jaybird / About to moult, / Look like he got on gloves / An' a overcoat." Weakened physically and financially, Slim hears the Lord's "call" to come save lost souls, an idea nurtured 
by seeing a former card-playing buddy whose similar conversion has netted "a house / Like de State Capitol" and a "wife / As purty as sin, / An' his secketary, twict / As purty again" (85). Clearly, the poem is scathing in its criticism of religious hypocrisy. But rhetorical embellishment, not Slim's "conversion," is the center of the poem. The techniques of tall tale, therefore, tone down the abusive criticism attributed to the poem.

In the poem "Elder Mistletoe," Brown turns the table and shows that the clergy was not the only group subject to hypocritical practice. Church folks were also capable of feigning beliefs and virtues. Like Job, Elder Johnson "was long patienced," but because "de Elder's salary / Was forty months behind, / De deacons board-it passed de vote / To pay him off in kind." After being offered a variety of foodstuffs fit only for sows, Elder Johnson refused their good offices and prepared to exit the pulpit: "Den he turned to leave de rostrum / And on his coat below / Tied wid a little red ribbon / Was a sprig of mistletoe" (150). This bit of irreverence, although lighter in tone than "Slim Hears 'The Call,'" reveals Brown's belief in not glorifying the folk but in showing their warts and beauty too.

In one last example, "Sister Lou," Brown locates the epitome of sincerity and authentic spiritual belief, not in conceptual terms as in "racial uplift," but in the souls of Black folk. "Sister Lou," suffused with apocalyptic imagery, represents the view of heaven Brown gained from the people themselves. In an essay, he describes their meaning of heaven as simple satisfaction, home, rest, and acceptance as a person..$^{21}$ No other Brown poem concludes so poignantly, so brilliantly: “Den take yo' time.... / Honey, take yo' bressed time" (55).

What then are we to make of Sterling Allen Brown's double consciousness? First, we know Brown faced dilemmas and had to make a number of choices. I'm sure he said to himself: "I want to be an American, but America won't accept me!! What do I embrace?" One prospect was that he could resolve the whole issue by simply "passing." Religion, as his father practiced it, provided an opportunity to pass. The life of Washington's Black middle class, into which he was born, offered privilege. His Harvard University MA, a degree some equated to a PhD from other schools, was another chance to pass. The ultimate opportunity, of course, was his light skin color, which could have enabled a complete disappearance across the racial line. Whatever temptations were afforded by these opportunities, Brown refused them in favor of being a Negro, as he said, like DuBois, James Weldon Johnson, and Paul Robeson.

Somewhat like DuBois, Brown felt that white America had a jaundiced view of life behind the Veil. As a poet-scholar-teacher, steeped in the literary traditions of England, France, Russia, and the New American Poetry, he fought through art and essay to correct Black racial misrepresentation by providing authentic views of Black life by lifting the Veil for all to see clearly and steadily the humanity of Negro people. For this reason, he embraced the folk as embodying the "true" characteristics of Black racial identity and culture.

Anecdotally, we are given an important indication of his decision when he was a student at Williams. He recalls listening to his first blues, Mamie Smith's vaudevillesque rendition of "The Crazy Blues" (1920). ${ }^{22}$ To appease roommates embarrassed by this new musical form, Brown pulled the shutters of the victrola down and 
draped a towel over it to muffle the sound. Can you imagine that towel as a sort of Veil? And Brown's pulling the Veil back to examine a whole cultural history? This gesture represents an inchoate movement, but one signifying the beginning of a lifelong exploration. Yes, the double conscious brother would discover in this moment his own life service, which he would develop out of the pain and laughter of his own people, using his people's words.

\section{NOTES}

1. Jervis Anderson, “Our Far-Flung Correspondents (Dunbar High School)," The New Yorker, 20 March 1978, p. 107.

2. Anderson 107.

3. Jean Wagner, Black Poets of the United States (Urbana: University of Illinois Press, 1973), 501.

4. See Paul Gilroy, for example, who conceives "double consciousness" as an organizing principle for DuBois to explore issues of identity-issues that problematized not only "the experience of post-slave populations in general" but also DuBois's "dream of global co-operation among peoples of colour which came to full fruition only in his later work." Paul Gilroy, The Black Atlantic: Modernity and Double Consciousness (Cambridge: Harvard University Press, 1993), 126. Or Sandra Adell, in her critical study Double-Consciousness / Double Bind, reads DuBoisian double consciousness in terms of Western philosophical thought, thereby seeking to prove that recent critics attempting to define a Black aesthetic are doomed to failure. Sandra Adell, Double-Consciousness / Double Bind: Theoretical Issues in Twentieth-Century Black Literature (Urbana: University of Illinois Press, 1994). Others, such as Denise Heinze in her study of Toni Morrison's novels, now refute the concept's original effort to merge two conflicting identities by arguing that Morrison, who purportedly writes for a white and a Black readership, manages "'a rare accommodation' of the expectations of each." Denise Heinze, The Dilemma of "DoubleConsciousness": Toni Morrison's Novels (Athens: University of Georgia Press, 1993). I quote from Gary Storhoff's review in American Literature 66.2 (1994): 409. See also Christine Macleod's review in MLR 90.2 (1995): 429-30.

5. Michael Awkward, Inspiriting Influences (New York: Columbia University Press, 1989), $66-67$.

6. Sterling A. Brown, "A Son's Return: 'Oh, Didn't He Ramble,'" in Chant of Saints, eds. Michael S. Harper and Robert B. Stepto (Urbana: University of Illinois Press, 1979), 18.

7. Booker T. Washington, Up From Slavery (1901; New York: W.W. Norton \& Company, 1996), $104-5$.

8. See "Lost in a Cause: Booker T. Washington's Up From Slavery," in his From Behind the Veil: $A$ Study of Afro-American Narrative (Urbana: University of Illinois Press, 1979), 32-51.

9. Rev. Sterling N. Brown, My Own Life Story (Washington, D.C.: Hamilton Printing Company, 1924), 19-20.

10. Rev. S. N. Brown, "How Can the Friendly Relations Now Existing Between the Two Races in the South be Strengthened and Maintained?" in Twentieth Century Negro Literature: or A Cyclopedia of Thought on the Vital Topics Relating to the American Negro (Naperville, IL: J.L. Nichols \& Co., 1902), 68-71.

11. Rev. Brown, My Own Life Story, p. 17.

12. Sterling A. Brown, quoted in Profiles of Black Achievement: Sterling Brown / Alma Thomas (Pleasantville, NY: Guidance Associates, 1973), 32.

13. Rev. Brown, My Own Life Story, pp. 18-19.

14. quoted by Michael S. Harper, "To the Reader: Re STERLING A. BROWN," Every Shut Eye Ain't Asleep, eds. Michael S. Harper and Anthony Walton (Boston: Little, Brown and Company, 1994), v.

15. In his Harvard University course thesis, Brown wrote: "[John Millington Synge] went to the [Aran Islands] as a poet, seeking the real quality of the folk, not as a social scientist amassing statistics. His poetic insight availed, he has left us unforgettable pictures of the dignity of these inarticulate people, their courage in the teeth of harsh adversities, their noble humanity." In Plays of the Irish Character: A Study in Reinterpretation (1932), 62.

16. quoted by James Spady, "Sterling A. Brown Honored at UMUM Fete in Washington, D.C.," The Oracle: Official Organ of Omega Psi Phi, 61. 2 \& 3 (Summer-Fall 1977): 15. 


\section{A L L A L O O}

17. All page references are to The Collected Poems of Sterling A. Brown (Evanston, IL: TriQuarterly Books, 1983).

18. Sterling A. Brown, "In the American Grain," Vassar Alumnae Magazine, 36.3 (1951): 6.

19. Brown 6. See also John Edgar Tidwell, "The Art of Tall Tale in the Slim Greer Poems," Cottonwood 38/39 (Summer/Fall 1986): 170-76.

20. Wagner 493.

21. "Negro Folk Expression: Spirituals, Seculars, Ballads and Work Songs," Phylon 14.1 (1953): 47.

22. We should keep in mind that in Brown's apprenticeship as poet, his understanding of the poetic possibilities of Black language was initially shaped by minstrelsy, vaudeville, musical comedies, and other Tin Pan Alley expressive forms. Thus "Crazy Blues," even though written by an African-American composer, was a blues in title only. Also, Sophie Tucker was originally scheduled to record this song, the one that launched Okeh Records's successful foray into "race" records. When Tucker became ill, composer Perry Bradford persuaded the company's white recording director, Ralph Peer, to let Mamie Smith do it. As Eileen Southern reports in her The Music of Black Americans (1971), the sale of 7500 discs per week broke all sales records and prompted such entrepreneurial ingenuity as the hiring of Negro talent scouts to locate the best singers and musicians (398). Commercialization inevitably became a by-product of this success, leading to Tin Pan Alley versions having little or no relation to actual Black life. 